\title{
Raupatu: A Waikato Perspective
}

This article will discuss the concept of raupatu, of land confiscation. It will also examine the significance of this concept to the Waikato people.

Raupatu or the conquest of land is a concept that has become a heavy burden upon the hearts and minds of not only the Waikato people, but also upon many Māori people across Aotearoa/New Zealand. This burden has been passed down through the generations of Waikato people to the extent that it has become a part of Waikato identity. Raupatu has affected Indigenous peoples all over the world.

The main objective of this presentation is to give a Waikato perspective on the concept of raupatu. To help describe a Waikato perspective of raupatu, interviews with three of my elders will provide insights into their innermost thoughts on this matter. These elders were Motu Katipa, Pinepine Herewini and Mamae Tākerei. The stories and thoughts they provided are treasured pieces of our people's history and I am eternally grateful and honoured that they allowed me to interview them.

\section{The establishment of Te Kingitanga}

To fully understand the concept of raupatu it is important to understand the historical background of the Waikato people and the events that led to the invoking of raupatu over our lands. This will provide a useful context for the main part of my presentation. The only way I know how to describe a Waikato background is by talking about the Kingitanga, or the Māori King Movement.

Pōtatau Te Wherowhero was the first Māori king. There is some debate on the actual year he was crowned but the date passed down to me by my elders is 2 May 1858. However, the search for a king began well before this date. In the years Dean P. S. Mahuta is a PhD student and Assistant Lecturer (part-time) in Te Ara Poutama, Faculty of Māori Development, AUT University. His doctoral thesis will look at the history of the Waikato River and the strong bond between the river and the people who share its name. 
before the Kīngitanga, both Pākehā (non-Indigenous people of Aotearoa/New Zealand) and the Waikato people had quite a prosperous relationship in that trade between the two was beneficial to both peoples.

The Kingitanga was formed to unify the Māori people, and it was created under three other precepts. The first was to bring an end to inter-tribal warfare. With trade came the introduction of muskets, and these weapons brought a new dynamic to inter-tribal warfare, as Māori were dying in larger numbers than in pre-contact battles. The Kingitanga aimed to bring an end to warfare. The second was to keep Māori land in Māori hands because Pākehā were beginning to buy up as much Māori-owned land as they could by whatever means necessary. The third was to have a separate governing body from the settler Government that would attend to the interests of Māori first and foremost, as well as having an entity that would be equal to the Queen of England. In essence, the Kingitanga would provide self-governance and selfdetermination for Māori as a nation of Indigenous people.

Before the appointment of Pōtatau Te Wherowhero as king, the idea of establishing some type of monarchy for Māori began in the early 1850s with Piri Kawau of Te Âtiawa, in the Taranaki region. On a trip to England, Kawau saw how Queen Victoria commanded her soldiers and was so impressed with their loyalty to their Queen, that he wished himself to be King. On his return however, his people did not agree with him, and he was denied that wish. It was then that Tamihana Te Rauparaha also saw the Queen's command of her military, and made a bid to be King, but it was his father, the great Ngāti Toa chief, Te Rauparaha, conqueror of the Kapiti Coast, who told his son that his power was limited due to the fact that Ngāti Toa was driven from Kāwhia on the west coast of the North Island by Waikato. ${ }^{1}$

It was Mātene Te Whiwhi of Ngāti Raukawa who would not let this idea of a Māori monarch die. Along with master genealogists he approached Pōtatau Te Wherowhero to be king, but he declined, as he did not want that responsibility. Instead he told them to look to the other tribes for a king. So the search began in Taranaki with the chief Whitikau. Like Te Wherowhero, Whitikau and Tōpia Tūroa of the Whanganui area did not want the responsibility. Mātene Te Whiwhi then went to Te Heuheu Tūkino, high chief of Ngāti Tūwharetoa, the tribe of the Taupō district. He also did not want the burden of the Kingitanga. After travelling through other areas of 
Aotearoa, one important stop was made in the Hawkes Bay on the East Coast of the North Island, where the mantle of the Kingitanga was brought before Te Kani-a-Takirau. He also refused, saying that he was already a King, but put forth the name of his cousin Karauria as a prime candidate. ${ }^{2}$ All were about to agree when suddenly Te Hūkiki, one of the master genealogists, declared that Pōtatau Te Wherowhero's whakapapa was senior to that of Karauria. Pōtatau's whakapapa was also unique in the sense that, as well as coming from a direct line of ariki, or high chiefs, he had genealogical links to all the major waka (confederation of tribes who claim descent from the people who migrated to Aotearoa/New Zealand on a particular canoe). Before returning to see Pōtatau, the mantle of the Kingitanga was then returned to Tüwharetoa, to the then chief, Te Heuheu Iwikau, son of Te Heuheu Tūkino. His response was that Queen Victoria was someone with many possessions and so declared that our King should be someone of similar wealth. Te Heuheu Iwikau endorsed the appointment of Potatau as the King, because Waikato were a people with a wealth of fertile land and were surrounded by several great tribes. Furthermore, Waikato would have the ability to host hui or gatherings on a very large scale. In one last effort to find another suitable candidate for the kingship, Pōtatau offered up Tānirau of Ngāti Maniapoto, saying, 'E tō te rā ki a au' (The sun is setting with me.) This meant that he was too old and that he would soon die. However, Tānirau was clever to respond with, 'He rā e tō, he rā e puta mai anō' (The sun will set, but the sun will rise again.)

It was this last statement that finally persuaded Pōtatau to accept the responsibility of the Kingitanga. This statement also established the hereditary nature of the Kingitanga. Several crowning ceremonies were held so that the masses could witness the establishment of the Kingitanga. The last one was held in Ngāruawāhia, where all the major tribes of the North Island gathered and laid their lands and loyalty before Pōtatau, thus consolidating Māori-owned land in a protective seal from settler land grabbers. Pōtatau's line has since been the figurehead of the Kingitanga and Waikato its caretakers.

Tāwhiao, Pōtatau's son, succeeded him in 1860. King Tāwhiao reigned during the harsh years of the Waikato Land Wars that resulted in the confiscation of Waikato land. He also witnessed his people's fall into the depression of land alienation, which was followed by his exile out of Waikato. He 
is famous for his tongi, or prophetic sayings, that Waikato still look to today for guidance.

Succeeding King Tāwhiao was his son, Mahuta, in 1894. During his reign he was offered a seat on the Legislative Council of the Colonial Government and accepted with promises that he would effect real change for his people in terms of the return of confiscated lands. This promise would never amount to anything and his position became tenuous. With Mahuta's death, his son, Te Rata, became King. $\mathrm{He}$ travelled to England to seek an audience with the Queen but was never allowed to see her. From this trip came a famous saying, 'I haere Māori atu, i hoki Māori mai' (I went as a Māori and I returned a Māori), signalling to the people that his trip was not successful. During King Te Rata's time also came the decree that became the basis for Waikato's search for redress, which was ' $i$ haere whenua atu, me hoki whenua mai' (As land was taken, so should land be returned.)

His son, Korokī, who was a healer and man of great kindness, succeeded Te Rata. Te Arikinui Kuini Te Atairangikaahu was the first Māori Queen and the sixth heir to King Pōtatau Te Wherowhero. In May, 2006, she celebrated her 40 years as Queen but died later in the year, to be succeeded by King Tūheitia. One of the significant achievements of Te Arikinui Kuīni Te Atairangikaahu's time took place on 22 May 1995 when she signed the Deed of Settlement that finally saw the Crown acknowledge that the confiscation of Waikato lands was unjust and that they were wrong to label Waikato as rebels. The Crown also took responsibility for the many Waikato people who died defending their lands, as well as acknowledging the effect land alienation has had on Waikato as an iwi.

The Kingitanga has survived for 150 years and for Waikato, as caretakers of this treasure, it has been the foundation of our traditions, our history, our relationships and our families. It is the ideals that King Tâwhiao left us that continue to provide guidance to the people today. Thus to know and understand Waikato is to know the Kingitanga.

\section{Defining raupatu}

In my search for a definition or explanation of raupatu, I first went back to my elders to find out what raupatu means for Waikato. Their initial ideas were basically all the same. 
Firstly they broke the word up into its parts, rau and patu. Rau means 'one hundred' and patu ${ }^{1}$ means 'to hit', 'to attack', or in the case of land confiscation 'to kill'. So the meaning of raupatu refers to the hundreds of people that were killed (by the blade of the patu) in the confiscation of land. As two of my informants, Pinepine Herewini and Mamae Tākerei claimed:

I suppose it's the same as muru, 'raupatu', 'rau' meaning hundreds and patu means to hit, patu tangata, that's how I think about it. ${ }^{3}$

Ko te rau i mate ai mō te whenua te take, ko te patu i patungia te rau raka kia mate. Now ... if you look at 'ko te rau, ko te patu,' put them together and in terms of 'rau' as in hundreds of people that died for the land, 'patu' ko te patu i pā ki te pane, ki te rae o te tangata, i mate ai, he aha te take, he wăhine, he whenua (the club that would hit the head or the brow of a person, for what reason, for women and for the land), other people might have different interpretations. ${ }^{4}$

I asked the question of these elders as to whether Waikato had an understanding of raupatu before the arrival of Pākehā settlers. In answer to this question, Mamae Tākerei said, 'Was there ever a specific meaning for raupatu in Pre-European times? Was there a need for that word? Or did the term become configured by way of confiscation?' When I researched this idea I found that raupatu had indeed two main conditions that had to be fulfilled in order for raupatu to be correctly applied. The first is the act of battle that determines the victor and the second is the undisturbed occupation of the land by the victors. Hirini Moko Mead has this to say about these conditions in his book Landmarks, Bridges and Visions. Aspects of Māori Culture:

It must be emphasized that the defeat in a single battle did not automatically confer the right of ownership; rather, it was the defeat combined with the undisturbed occupation of land. ${ }^{5}$

Mead says that this condition of raupatu is considered ringa kaha where the land is held by way of force and there has been no challenge against the victors for possession of the land.

${ }^{1}$ Patu is a club type weapon made of wood, stone or bone. 
The term for the second condition, undisturbed occupation, is ahi kā, which literally means 'burning fires'. This term is in reference to the people keeping the home fires burning. As the fires are kept burning, so too is the connection of the people to the land. Only by occupying the land without challenge for several generations is ahi kā established. Ahi kā relates to whakapapa (genealogy), and the notion of keeping the fires burning refers to the continuation of each generation upon the land. The more generations that remain ahi kā through whakapapa, the stronger the connection will be to the land. Mamae Tākerei had this to say about ahi kā:

There's those people left behind, that's the second wave right here, you've got those who at the point of landfall made occupation. Those who were left behind as the ahi $k \bar{a}$, to preserve the land to keep it alive ... the descendants become the ahi $k \bar{a} \ldots{ }^{6}$

This is one of the main reasons for raupatu having such a devastating effect on the people of Waikato. Waikato's connection to the land goes right back to the migration to Aotearoa/New Zealand, where several of Waikato's ancestors first journeyed across this land, and claimed the lands that Waikato call home.

Greed became the master of the European/Pākehā settlers, and the need to have Māori-owned land overpowered the thoughts of the settler Government. After the signing of the Treaty of Waitangi in 1840, Pākehā were quick to create legislation that gave them the power to take and enforce whatever they wished. Before the Land Wars of 1863 that resulted in the confiscation of Waikato lands, the relationship between Waikato and Pākehā settlers in Auckland had been a prosperous one. The fertile lands of the Waikato created a thriving agricultural industry for the people, where Waikato grew produce such as corn and potatoes. This produce was then shipped to Auckland, mainly for the Pākehā settler population. Michael King called this period the 'Golden Years' for Waikato. Thus the need to have control of a huge agricultural industry was a main factor in the Crown's decision to confiscate Waikato lands.

Grey and others also perceived the Kinngitanga as a major opposition to their control of Aotearoa/New Zealand. For example, some Kingitanga warriors fought the Crown in Taranaki, and they were therefore keen to suppress it. Land 
confiscation was, presumably, in part to punish and keep its supporters weak, by imposing European settlement on the land. For some Pākehā, European settlement in Māori areas was seen as a positive development, as they thought Māori would then be integrated into the 'superior' civilisation brought to Aotearoa/New Zealand by the English colonists. They genuinely believed that the savage Māori would be civilised and become like Pākehā.

So, how did the arrival of Pākehā affect the Māori concept of raupatu? In the first instance, Pākehā settlers and the Crown's military forces themselves were the first problem, in that they did not have any appreciation of a Māori world view. According to Mead, 7 even when Māori tribes fought one another, if one tribe was under the influence or were supported by a European military force, then the lands would not be considered whenua raupatu or confiscated lands. Furthermore, the two conditions of ringa kaha (military force) and the establishment of ahi kā and the undisturbed occupation of the land were never achieved. Even if Pākehā obtained the land through military force, Māori have continuously challenged Pākehā for the return of confiscated lands. They have done this by remaining on the land, thereby maintaining the right of ahi kā.

For a Waikato perspective, I quote one of my elders, my kuia, Pinepine Herewini, who says:

With raupatu now, it's a term for money, that's my understanding of it ... Raupatu is not a nice thing, when people talk about raupatu, it makes one knock back or cringe you know. It's just, what was involved with it, that's the hard part too. When people talk about raupatu now, it's about people, money and pain. ${ }^{8}$

Pinepine Herewini refers to the 'money' that gets exchanged between the Crown and the people as a means of trying to seek retribution; the 'pain' refers to the heavy burden on the hearts of Waikato people due to the loss of life. The 'people' are those who gave their lives for the land, for our ancestors who had to endure being alienated from the land, for those who paved the way for the return of Waikato lands, and for all people past, present and future who have protected, and will continue to protect, the integrity of the land.

Motu Katipa, talked about growing up in a time of poverty, and where land alienation had occurred. During his youth the 
term raupatu was not used; rather, it referred to an understanding of the history of raupatu. He explained that during this time Waikato never had enough money. They were poor. For him raupatu referred to the Pākehā land confiscations that left nothing for the people. However, he knew the families moved to live beside the Waikato River, so that they could be close to the only source of food. This was the only way they could survive, by going fishing. Most of the time they had to go fishing at night. The only way they could earn any money was to go and work for the Pākehā doing jobs like cutting flax, clearing away swamps to make them ready for farming, and gum digging. These were all the hard manual labour jobs that no one else would do. Hardly any of the children could go to school. Those that did were the lucky ones. Because there was no land there was no money or income, and therefore nothing to clothe the people with. All of this was the result of raupatu, of land confiscation.

Raupatu was not a commonly used term by the older generation. For these people it was a concept used in relation to the history of the Land Wars and the effect of the Crown's confiscation of Waikato lands. Today, the term raupatu is used after these events to describe the people's feelings about the consequences of those days.

To conclude, raupatu alongside the Kingitanga is the heart and soul of the Waikato people. The effect of raupatu on the people is one that will stay with them forever. No matter how often a settlement is reached, one will never forget being ripped away from the very bosom of their mother, their ūkaipō.

Mamae Tākerei sums up raupatu by likening raupatu to theft. She locates her thoughts within the New Zealand Settlements Act 1863, which was the beginning of the land confiscations in Waikato:

Raupatu was theft. The New Zealand Settlements Act 1863 legalised the taking of land. There's only one word for it and that is theft ... The term 'raupatu' became synonymous with the theft of land and Māori promised, you know, the (death bed) saying that they would uphold, they would hold fast to the land. In the terms of raupatu our people fought to save the land because that was the physical being of all things wairua (spiritual), the land that was occupied by our forebears of how many generations, the land that was nurtured, that fed us, that had a spiritual purpose, it wasn't about money, and that's the difference between 'raupatu' then. After a post-Pākehā history and the difference between intentions of 'raupatu,' one 
was the spiritual context and what it provided for our people, it gave us strength, not a fiscal strength but a spiritual strength. It nurtured us. We were able to identify with the land. Our whakapapa was in land. With Pākehā the difference between what I'm saying now, and the Pākehā term, was money. It was about colonialist opportunity, it was about sale, it was about commercial viability, it wasn't about anything that I describe that has an allegiance and an alliance with Māori thinking. Especially Waikato, it is fertile land, it offered us life, saviour, it gave us strength, physical, spiritual, it enabled us to whakapapa, in which when you line those up with what Pākehā interpretation of what raupatu is. One is money, the other is life, before and after death, the land will always be there, it will always be a living testimony for what our people died for. That's what land is all about, that's what raupatu is all about then, and this is what it was about for Pākehā after the 1863 Act it was about money, nothing else. ${ }^{9}$

In the words of King Te Rata, 'I haere whenua atu, me hoki whenua mai' (As land was taken so should land be returned).

\section{Notes}

1 A. Ballara, (ed.), Te Kingitanga. The People of the Mãori King Movement. From the Dictionary of New Zealand Biography, Auckland, 1996, p. 1.

Ibid., p. 3.

Herewini, 2004, personal communication.

Tākerei, 2004, personal communication.

S. M. Mead, Landmarks, Bridges and Visions. Aspects of Māori Culture, Wellington, 1997, p. 228.

Tākerei 2004, personal communication.

S. M. Mead.

Herewini, 2004, personal communication.

Tākerei, 2004, personal communication. 